\title{
Toward a Restricted Tolerance of Street Vending of Food in Hanoi Districts: The Role of Stakeholder Dialogue
}

\author{
Nguyen Thi Tan $\operatorname{Loc}^{\mathrm{A}} \&$ Paule Moustier ${ }^{\mathrm{B}}$
}

In Vietnam, fruit and vegetable marketing is characterized by a diversity of distribution chains, including formal markets, street vendors, shops, and supermarkets. The government is promoting the expansion of supermarket distribution and plans to eliminate all informal trade on the grounds of modernization. The article investigates how the activities of street vendors can be successfully integrated in the city, using a stakeholder dialogue approach. Researchers appraised the role of street vendors in food distribution and employment and documented a successful street vending model. Stakeholder meetings were held to discuss the integration of street vending in Dong Da District. A key result is the demonstration and recognition by city and district officials of the dominant role of street vending in food distribution and employment of the poor. Workshops helped the Hanoi city and district authorities agree to tolerate streetvendors in selected areas, with thesetting of jointly developed commitments.

Keywords: Street vendors, Vietnam, food distribution, stakeholder dialogue, informal markets

\section{Introduction}

$\mathrm{D}$ uring the past 20 years, the food sector in Vietnam has undergone major changes. The reforms implemented in the framework of the doi moi, or "renovation" policy, have been reflected in spectacular economic growth, particularly in cities. In 2013, the growth rate of the economy was 5\%, the urbanization growth rate $3 \%$, and the urbanization rate $33 \%$, contrasting with
$25 \%$ in 2002. Economic and demographic changes have caused an increase in the demand for more diverse and better quality produce, especially in urban areas. The food distribution sector has adapted to these changes and has now taken on a diversity of forms. In Hanoi, a person can purchase foodstuffs from a variety of sources ranging from street vendors to air-conditioned hypermarkets, with shops and fixed market stalls in between (Figuié and Moustier 2009; Mergenthaler,

\footnotetext{
A Fruit and Vegetable Research Institute, Trau Quy, Hanoi, Vietnam.

${ }^{B}$ Centre de Coopération Internationale en Recherche Agronomique pour le Développement (CIRAD), UMR MOISA, France.
} 
Weinberger, and Qaim 2009). Yet, this diversity is currently threatened by the government's clear promotion of modern high-volume distribution and the planned eradication of informal trade activities, including that of street vendors. In the Vietnam context, we define street vendors as persons selling from baskets, motorbikes, or bicycles, usually moving from one place to the other, sometimes forming groups to sell on stretches of pavement or in other vacant spaces. This is in line with the definition given by Bhowmik (2005). The planned fast-track increase of supermarkets and elimination of temporary markets and street vendors is indicated in the strategy put forward by the Domestic Trade Department of the Ministry of Trade from the present until 2020, on the grounds of "modernizing" and "civilizing" commerce (Vietnam Ministry of Trade 2006). Regulation 36CP on traffic order and safety (dated February 2003) made street vending illegal, mostly because of traffic issues. However, in January 2009, street vending was actually recognized by Decision 46/2009 of the Hanoi People Committee, but prohibited on 63 major streets and some 48 public spaces including hospitals, squares, and bus stations.

At the same time, although Vietnam is praised for its success in poverty alleviation, poverty and unemployment are still major concerns for the government and donors. Poverty in Vietnam is mostly rural. In 2010, the average poverty rate was $20 \%$, while the urban poverty rate was between $6 \%$ and $7 \%$. Yet, urban poverty is underestimated as most migrants are not registered and do not benefit from social services. And the percentage of urban residents who suffer from non-monetary deprivations is much higher than the poverty rate (World Bank 2012; Thanh, Anh, and Phuong 2013).

Food distribution by itinerant vendors is well known to be a key factor in the social inclusion of the poor, as it creates small-scale business activities and has a positive impact in giving the poor access to food commodities. In Asia, their numbers have kept increasing in the last 10 years because of growing unemployment problems in cities, where in most of them it is estimated that informal jobs outnumber formal jobs (Bhowmik, op. cit.).

Making street vending an illegal activity and therefore making those who are engaged in it subject to a number of threats is not specific to Vietnam, as many countries in Asia and Africa have declared street vending illegal. The banning of street vending usually results from alleged traffic or health issues, often linked to modernization projects that favor large-scale and capitalintensive investments (Cross 2000). Asian governments typically have a policy of increasing formal employment and eliminating informal employment. A more pragmatic approach is to allow "semi-formality," in other words promote a self-regulating system with regulatory enforcement reduced to a minimum, thus protecting the flexibility of street vending which is uniquely adapted to the conditions of the urban poor (Cross, op. cit.).

The experience of other countries shows cases of successful integration of street vending in urban planning when street vendors are organized and dialogue is maintained with authorities. 
The organization of street vendors into advocacy groups is documented as the first step toward legalization, albeit partial.

Success stories of integration of street vendors in Kenya (Mitullah 2003) or India (Mahadevia et al. 2013) are in line with a stakeholder approach, which puts the economic agents who are affected by the policy decisions and actions of the system at the core of the decision processes (Grimble et al. 1995). The first objective of the article is to highlight the economic and social importance of fruit and vegetable street vending in Hanoi. The second objective is to show how stakeholder dialogue, based on such an evaluation and organized interactions between street vendors, urban authorities, consumers, and researchers, enables a more harmonious integration of food vending in the urban frame.

\section{Method}

$\mathrm{T}$ he method is based on the stakeholder approach in which we consider street vendors as entrepreneurs with objectives and constraints that are influenced by other stakeholders with whom they interact. It is noteworthy that while stakeholder dialogue based on scientific knowledge has been widely used in the field of natural resource management (Reed, 2008, Grimble et al. 1995), its application to food marketing issues is not frequent, which highlights the originality of the research paper. We consider it to be particularly relevant in a context of diverging interests and diverse perceptions that characterize the food street vending sector in Vietnam. Some stakeholders are particularly influential on street vendors' activities: their customers, police agents, as well as district and city officials from the department of trade. We assumed that their perception of street vendors may be influenced: (i) by the scientific knowledge that we could provide as international and local researchers on their social and economic role; (ii) by the way the street vendors express their objectives and constraints; (iii) and by the dialogue fostered among street vendors, police agents, district, and city officials, as well as local customers, on ways to reconcile diverging objectives. This perception influences their attitudes and actions toward street vending (see Figure 1). Hence, in this research, the article authors (termed as "we") acted at the same time as researchers and facilitators.

We made various studies of the street vendor activity in Hanoi to appraise their social and economic role. The first one was done in 2004 and updated in 2009 and 2013. We estimated the number of vegetable and fruit street vendors in Hanoi and the volume of goods sold by them. In 2009 and 2014, we also estimated the number and volumes traded by other points of sale to estimate the contribution of street vending to total food distribution. We interviewed a sample of street vendors to appraise the role of street vending in their livelihood and the impact of the legislation on their activities. This involved 60 street vendors in 2004 and 160 in 2013. A discussion paper was prepared based on the information generated, which provided the basis for a stakeholder workshop held in 2006, chaired by the Hanoi Department and Trade with the participation of a 


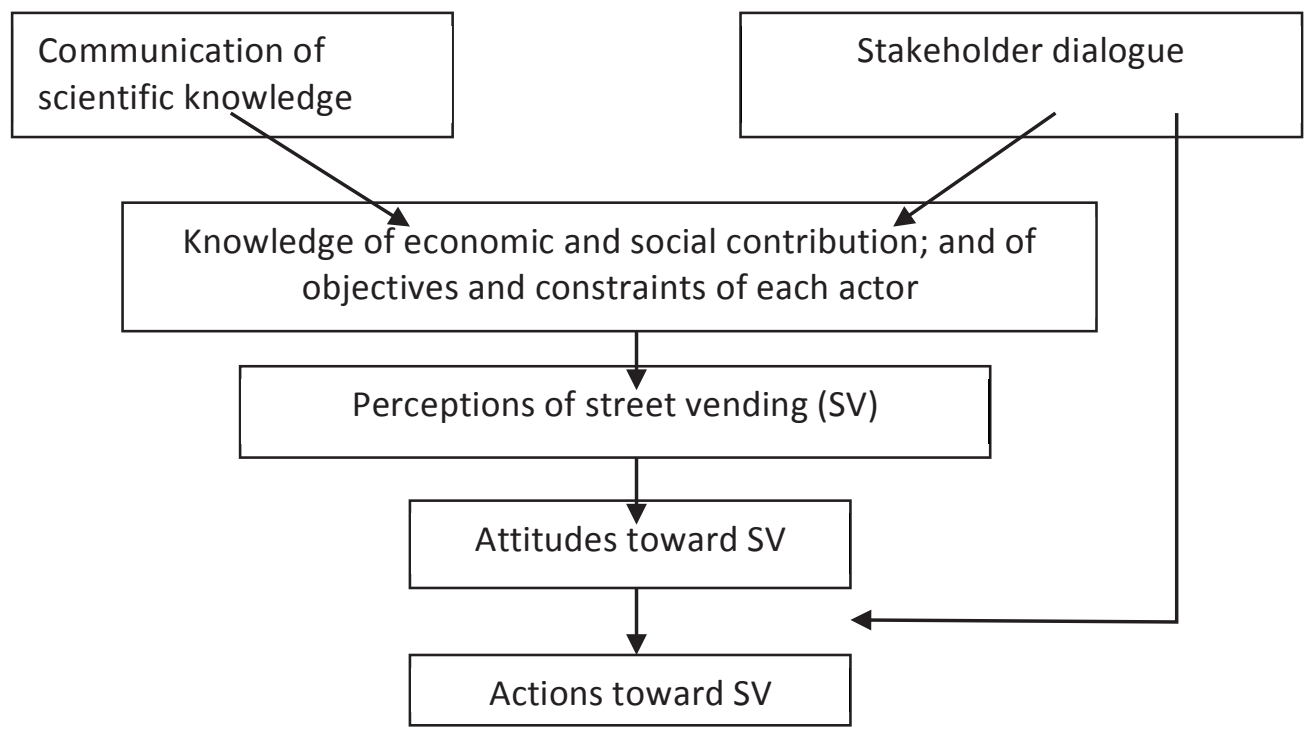

Figure 1: Conceptual frame

panel of street vendors, consumers, the heads of departments, and technical divisions dealing with agriculture and trade and included persons from market management boards, public security, the Department of Health, the Women's Union, the People's Committee of six different districts, as well as a panel of street vendors, along with the researchers involved in the study. In addition, in 2013, we documented one successful street vending model, in Kim Lien Ward in Dong Da District, by interviewing 16 consumers and 14 street vendors at this market.

On the basis of the gathered information, we organized a stakeholder dialogue process at the district level. In 2013, after interchange with the Hanoi Department of Industry and Trade, we organized three meetings bringing together street vendors and the competent authorities, including the Hanoi Department of Industry and Trade, district and ward officials, residential group representatives, and consumers in three wards of Dong Da District (Phuong Mai, Trung $\mathrm{Tu}$, and Lang $\mathrm{Ha}$ ). The meetings took place on March 8, March 14, and March 19, respectively. The objective was to discuss the results and to replicate the support from the authorities who helped unofficial sellers by giving them the permission to sell produce on vacant pieces of land and along deadend streets. We found the street vendors themselves require support in the form of raising their awareness of environmental sanitation, traffic safety, food hygiene, and food safety. We held three training courses for street vendors in these wards, with the participation of local officials. The changes in street vendors' behavior were assessed in these wards, which 
helped the local authorities see that they had grounds to continue their support for street vending activities.

In this article, we highlight the updated data on the economic contribution made by street vendors. We also present the results achieved by the stakeholder dialogue in Dong Da District and discuss the benefits of applying a stakeholder approach to the issue of street vending in Hanoi. This makes the article complementary to our previously published work on street vending in Hanoi (Moustier et al. 2007; 2009; Nguyen Thi Tan Loc et al. 2013).

\section{Selected results}

$\mathrm{W}$ e first present the results of our studies aimed at quantifying the economic and social role of fruit and vegetables street vending in Hanoi. Then we describe the successful experience in Kim Lien involving a street vendors' temporary market. This evidence served as the basis for stakeholder dialogue in Dong Da District, which will be presented at the end of this section.

The importance of street vending in urban food distribution

Consumer's surveys have shown that poor residents of Hanoi purchase produce mainly from street vendors due to its low price, freshness, and proximity to their homes (Figuié and Moustier 2009). Street vendors source vegetables mostly from wholesale markets (in urban areas) and partly from their own production. In 2009 , vegetable street vendors supplied $32 \%$ of the total vegetable volume sold to consumers, compared to $58 \%$ for retail markets, $9 \%$ for shops, and $1 \%$ for supermarkets. Until 2009, the number of vegetable street vendors increased at a higher rate than that of the city's population.

In 2014 , we estimated that $\sim 45 \%$ of vegetables were sold by street vendors, $49 \%$ at retail markets, with a limited volume being sold at stores (3\%) and supermarkets (3\%). This suggests an increase in the number of vendors and the volume they sell. We explain it by the movement of vendors from official markets to unofficial markets, especially along the road sides near factories, schools, or in front of someone's house or a store to avoid having to pay increasingly high fees in renovated official markets.

The importance of street vending for the livelihoods of the poor

The importance of street vendors in terms of poverty alleviation is both to the ones they serve and to the vendors themselves. Street vending not only contributes to delivering fruits and vegetables to low- and mediumincome consumers, but also improves the livelihood of urban and periurban residents with limited income opportunities. Street vendors are mostly female residents of Hanoi or neighboring provinces. They may once have been involved in agriculture, but their fields have been reduced in size due to urban development. They may still be able to grow some vegetables or buy vegetables from neighbors to sell in order to supplement their family income. With low qualifications, street vendors have limited options for employment 
although they are the main incomegenerating workers of their family. These street vendors consider street vending as a family profession. As a result, even though street vendors face daily risks and must work hard, they have to continue their street vending activity because they need the income it brings. However, street vending is not a stable occupation: it depends on external factors which cause many difficulties for the vendors.

\section{Threats to the business of street vendors}

Overall, two thirds of the street vendors interviewed had been arrested and fined at least once a month. This can happen on any street, whether street vending is prohibited on it or not. When street vending is not prohibited, they may be arrested for allegedly hindering traffic. The amount of the fine is about twice their daily profit. Yet, street vendors, especially the older ones, develop a range of strategies to avoid paying the fines, including playing on the "emotional guilt" of police officers and finding the weak spots in police surveillance (Turner and Schoenberger 2011).

An example of successful integration of street vending in the city

Recently, the authorities in some wards made efforts to help unofficial sellers to set up temporarily on vacant land or along low-traffic dead-end streets. The sellers manage such places by themselves and do not have to pay any fees. After each morning session of market selling, the vendors clean up the entire market space, which is then used as a playground in the afternoon (see Box $1)$.

Box 1. The example of Kim Lien market

The Kim Lien market is a model of successfully integrating street vending in the city. It sprung from the initiative of local residents, street vendors, and ward authorities in 2004 after a number of street vendors had been expelled from a street slated for widening. Initially, 20 street vendors began selling produce in this market, but the number has increased to the 70 currently. Street vendors are aware that the local leaders have made it possible for them to sell at the market. In acknowledgement, they feel responsible for keeping the area very clean.

The customers are mainly residents of Kim Lien ward, while a few come from elsewhere. The proportion of elderly or retired people in this ward is quite high and they choose to buy products in this temporary market because they do not have to travel far. Hence, they are supportive of the street vendors.

Phuong Mai ward has a street where informal marketing takes place along the lines of the Kim Lien market, thanks to the involvement of the head of a residential group. 
The results of stakeholder dialogue

We first present the rationale of stakeholder dialogue in Hanoi to contribute solving the problems related to street vendors. As explained in the introduction, the perceptions and attitudes of the district and city officials relative to informal food trade were initially negative and interventions were top-down. Our conversations with the officials and analysis of official documents (Hanoi Department of Trade 2010; Vietnam Ministry of Trade 2006) show that the informal food trade was considered as a leftover of backward activities, with a negative impact on traffic and food safety, and which should be made to disappear quickly and be replaced by supermarkets and markets equipped with cold storage and concrete buildings. The result was that facilities were provided to supermarket investors in terms of access to land, and building four "modern" retail markets on sites where the older markets previously stood (Geertman 2011; Hanoi Department of Trade 2010). It also resulted into the continuous harassment of street vendors by the police. But this top-down approach has many limitations. The fees to get access to market stalls are so prohibitively high that the number of street vendors decreased somewhat between 2009 and 2013 and has actually increased since (Nguyen Thi Tan Loc et al., 2013). At the same time, many consumers, especially the less well-to-do, prefer to get their supplies from vendors close to them, at low prices, rather than from distant supermarkets and markets which require fees for parking and where food is usually more expensive than that sold by street vendors.

Box 2. Some quotes by residents and street vendors

Mrs N.T.T., a resident of Phuong Mai ward stated: "Areas where street vendors commonly sell products are in essence small markets. They are a feature wherever low-income consumers live. Street vendors sell produce at price levels that suit them. However, we are concerned about the quality of vegetables sold. Therefore, we hope that the ward authority will arrange frequent spot checks on the quality of vegetables."

"I have been retired since 1986. To ensure my family's daily subsistence, the only income-generating activity I can do is vegetables street vending," said Mrs NTD in Quang Trung Ward. She adds: "I often purchase vegetables at the Phung Khoang wholesale market because they are mainly from safe vegetable growing areas in Dong Anh District." She concludes by expressing the wish that "the ward will arrange a stable area for street vendors." 
Consumers found it important to have makeshift selling points to meet the demand of the local residents, especially elderly persons who have restricted mobility and financial capacity. Consumers highlighted the advantages of these points: low prices, freshness, and friendly relationships between sellers and consumers. However, they are concerned about produce origin (in particular, they prefer vegetables that originate from periurban areas where production conditions have been certified as "safe" by Hanoi authorities) and accurate weighing by street vendors. If these concerns were addressed, street vending would be fully supported by the residents (see Box 2).

The street vendors pointed out that their activity generated employment and income for themselves and their families. There is no other activity that they can engage in. Hence, street vending contributes to employment, family stability, and social security. Street vendors, often farmers themselves, say that they pay attention to the way the vegetables are produced and make purchases of vegetables based on their origin (see Box 2).

As for the difficulties faced by street vendors from the police, the police representatives replied that street vendors frequently disrupt traffic by crossing streets just anywhere or setting up on places that obstruct traffic.

The main objectives and constraints of stakeholders are summarized in Table 1.

Based on the experience in Kim Lien market and Phuong Mai Ward, participants reached a consensus on what makes a good street vending model. First, there must be a meeting of minds among the residential group leaders. A representative of the residential group is needed who is willing to take some risk and build a relationship with the Communist Party secretaries of the residential groups and local Women's Union. This ensures the support of the ward leaders. Second, there must be cooperation on the part of ward leaders who understand the street vendors need to earn a living. In all cases, there

Table 1. Main objectives and constraints of stakeholders

\begin{tabular}{|l|l|l|l|}
\hline & Street vendors & \multicolumn{1}{|c|}{ Residents } & \multicolumn{1}{|c|}{ Policemen } \\
\hline Objectives & Livelihoods & $\begin{array}{l}\text { Cheap access to } \\
\text { food } \\
\text { Trust in food } \\
\text { safety }\end{array}$ & Fluid traffic \\
\hline Constraints & High fines & $\begin{array}{l}\text { Little knowledge } \\
\text { on origin of food }\end{array}$ & $\begin{array}{l}\text { Torn between } \\
\text { compassion and } \\
\text { duty }\end{array}$ \\
\hline
\end{tabular}


must also be good cooperation with the residential groups where street vendors operate. Crucially, in order to maintain this model in the long term, a consensus among the ward, district, and city leaders is needed. This is only possible when street vending is allowed in specific areas, such as on plots of vacant land, unoccupied yards, stretches of pavement, or the like, and is under good management, keeping its impact on traffic, the environment, and urban landscape to a strict minimum. The cooperation, involvement, and support of the city, district, and ward leaders is crucial in order to set up local marketplaces for street vendors.

A valuable point noted by the research team is that the stakeholders across the board must share in the effort.

- People living around the marketplace need to accept a bit of noise and loss of space where street vendors set up on both sides of the street.

- Street vendors must maintain order, discipline, tidiness, and cleanliness.

- Garbage collection workers should cooperate to help clear up waste after each market session, sharing the work with the street vendors.

The leaders of residential groups must be responsible for seeing that street vendors sit at their designated places and that cleanup is done after the market session. They must also look into the quality of the produce sold and remind street vendors of their obligations as needed.

Ward, district, and city leaders expressed their interest in working toward this model. Moreover, the street vendors participating to workshops said that they would like to raise awareness among other street vendors about the need to comply with street vending regulations. They also specifically asked for support to overcome problems with food safety. They want other vendors to be well-informed in order to reduce risks, deal with hygiene issues, identify unsafe vegetable and fruit produce, as well as risks in the process of produce selection and sales. There was a consensus on the necessity to sustain the successful cases of integration of street vending in the wards, e.g., Kim Liem market, and to replicate this experience in other areas.

\section{Conclusions}

The research we presented demonstrates how a stakeholder approach can help to overcome the hostility that authorities and consumers may feel toward street vendors. This means providing a better understanding of the objectives and constraints on both sides. The literature review shows that rather than trying to convert informal activities into formal activities, a more pragmatic approach is to upgrade them in the context of developing economies (Bhowmik, op. cit.).

The research on fruit and vegetable street vending enabled the research team to demonstrate the significant contribution of this activity to the livelihoods of the poor and to food distribution. From the standpoint of the authorities and consumers, street vending activities bring advantages but admittedly may be a cause of traffic obstruction and give rise to consumer concerns over food safety. 
The main outcomes of the research and consultation are that management staff at the ward and district levels as well as within the Department of Industry and Trade now have a fuller understanding of street vending and see the importance for leaders to facilitate things to allow street vendors to operate in residential areas. This approach was original in that local residents-the customers of the street vendors-were involved in the consultation. The example of the Kim Lien market and street vending in Phuong Mai Ward shows that groups of customers can take a sustained interest in promoting the activities of street vendors, in tandem with the local authorities who give permission for vacant land to be used. Street vendors themselves commit to following traffic and food safety regulations. In this way, the street vending becomes "semiformal," so to speak, which means that the system of stakeholders is self-regulating. Regulations are enforced while flexibly and entry barriers to trading activities can be kept low for the benefit of less affluent urban residents (Cross op. cit.). Some elements in our work on promoting stakeholder recognition and dialogue for a better integration of informal activities in a city can be replicated, even though the political context is quite specific. In Hanoi, it is particularly difficult to foster collective action by street vendors because of the attitude of local authorities who consider that any form of organization should come from their initiative and operate under their control. So we had to invite a panel of street vendors representing a diversity of socio-economic profiles and have them agree to disseminate information to their acquaintances rather than acting as actual representatives of the vendors. Further, support was sought from the Women's Union at the city and local levels, given its rather direct interest in this issue. The general lessons can be summarized as follows: first, this action-research shows the importance of gathering rigorous qualitative and quantitative data on the benefits and drawbacks of the informal activity under focus. Researchers are also particularly helpful in documenting success stories of the inclusion of informal activities in the city, internationally, and locally. Second, it suggests that confining the scale to the ward or district may make it easier to implement fruitful stakeholder dialogue than taking on the scale of the city. This more localized scale is also relevant to identify and document innovative solutions to the problems posed by street vending. Third, having informal traders, consumers, district and ward officers as well as researchers involved in the dialogue process led by skilled facilitators, getting all to express their views on the issue at stake, reaching a measure of consensus and making commitments on solutions to the problems raised, are important ingredients for success. As a follow-up, it would be necessary to regularly monitor the process put in place and facilitate further stakeholder dialogue. From a research perspective, investigating recent insights from policy and planning sciences, including Public Participation, would also be very valuable (Innes and Booher 2004; Walker, McQuarrie, and Lee 2015). 


\section{Acknowledgments}

The research was first carried out between 2008 and 2010 in the framework of a collaboration between "Markets for the Poor," a project funded by the ADB and DFID, and MALICA, a research consortium on food markets in Asia which includes CIRAD, VAAS, and IPSARD. In 2013, DFID, through the Sustainable Markets program of IIED, funded an updated documentation of the role of street vending in Hanoi and new stakeholder consultations. This resulted in a publication of an IIED paper in 2013. Finally, some new market surveys were conducted in 2014 in the context of Nguyen Thi Tan Loc's Ph.D. thesis, with financial support from CIRAD.

\section{References}

Bhowmik, S.K. 2005. "Street Vendors in Asia: A Review." Economic and Political Weekly, 2256-2264.

Cross, J. 2000. "Street Vendors, and Postmodernity: Conflict and Compromise in the Global Economy." International Journal of Sociology and Social Policy 20 (1/2): 29-51.

Figuié, M., and P. Moustier. 2009. "Market Appeal in An Emerging Economy: Supermarkets and Poor Consumers in Vietnam." Food Policy 34 (2): 210-217.

Geertman, S. 2011. "Fresh Markets, a Way of Life and Public Health Under Threat. Experiences in Europe and Asia and Action for Hanoi." Consultancy Report. Hanoi: Healthbridge.
Grimble, R., M.K. Chan, J. Agliontsy, and J. Quan. 1995. Trees and Trade-Offs: A Stakeholder Approach to Natural Resource Management. London: IIED.

Hanoi Department of Trade. 2010. "Overview of Current Status and Direction of Economic and Social Development in Hanoi in 2010, and 2030 Vision."

Thanh, H-X., T. T. Anh, and D. T. T. Phuong. 2013. "Urban Poverty in Vietnam: A View from Complementary Assessments." IIED Human Settlements Working Paper Series, $\mathrm{n}^{\circ} 40$. London: IIED.

Innes, J.E., and D.E. Booher. 2004. "Reframing Public Participation: Strategies for the 21st Century." Planning Theory and Practice 5: 419-436.

Mahadevia, D., A. Brown, M. Lyons, S. Vyas, K. Jajoo, and A. Mishra. 2013. Street Vendors in Ahmedabad: Status, Contribution and Challenges Report: Working Paper 20, Centre for Urban Equity. Ahmedabad: CEPT University.

Mergenthaler, M., K. Weinberger, and M. Qaim. 2009. "Consumer Valuation of Food Quality and Food Safety Attributes in Vietnam." Applied Economic Perspectives and Policy 31 (2): 266-283.

Mitullah, W. 2003. "Street Trade in Kenya: The Contribution of Research in Policy Dialogue and Response." Urban Research Symposium on Urban Development for Economic Growth and Poverty Reduction, Washington, World Bank, December 2003, 15-17. 
Moustier, P., M. Figuié, T.A. Dao, and T.T.L. Nguyen. 2009. "Are Supermarkets Poor-Friendly? Debates and Evidence from Vietnam." In The Crisis of Food Brands, eds. Lindgreen A., and Hingley M. London, New York, Gower and Routledge, 311-327.

Moustier, P., Nguyen Thi Tan Loc, Ho Thanh Son, and Hoang Bang An. 2007. "Promotion of Public-Private Dialogue to Maintain Poor-friendly Fruit and Vegetable Street Vending in Hanoi." Acta Horticulturae 794: 239-247.

Nguyen, Thi Tan Loc, Paule Moustier, Le Nhu Thinh, and Le Thi Ha. 2013. "Inclusive Urban Development? Making Space for Street Vending in Hanoi, Vietnam.” London: IIED.

Reed, M.S. 2008. "Stakeholder Participation for Environmental Management: A Literature Review." Biological conservation 141 (10): 24172431.

Vietnam Ministry of Trade, Department of Domestic Market Policies. 2006. The Strategy for Domestic Trade Development for the Period 2010-2015 and Development Orientation to 2020. Hanoi: Ministry of Trade, 30.

Turner, S., and L. Schoenberger. 2011. "Street Vendor Livelihoods and Everyday Politics in Hanoi, Vietnam: The Seeds of a Diverse Economy?" Urban Studies, 49 (5), 1027-1044.

Walker, E.T., M. McQuarrie, and C.W. Lee. 2015. "Rising Participation and Declining Democracy." In Democratizing
Inequalities: Dilemmas of the New Public Participation, eds C W. Lee, M. McQuarrie, E. T. Walker. New York: New York University Press, 3-22.

World Bank. 2012. "Well Begun, Not Yet Done: Vietnam's Remarkable Progress on Poverty Reduction and the Emerging Challenges." Report. Hanoi: World Bank. 